\title{
IMPLEMENTASI ALGORITMA RANDOM PADA PERMAINAN KETANGKASAN
}

\author{
Zuly Budiarso ${ }^{1}$, Eddy Nurraharjo ${ }^{2}$ \\ ${ }^{1,2}$ Program Studi Teknik Informatika, Fakultas Teknologi Informasi, Universitas Stikubank \\ email: 'zulybudiarso@edu.unisbank.ac.id, ${ }^{2}$ eddynurraharjo@edu.unisbank.ac.id
}

\begin{abstract}
Abstrak
Permainan telah merambah berbagai usia, mulai dari usia muda hingga dewasa. Permainan merupakan salah satu mediasi perantara dalam olah tubuh, baik fikiran maupun fisik, bahkan sudah merambah kombinasi keduanya. Berbagai jenis permainan telah banyak dikembangkan diantaranya permainan berbasis perangkat komputer, perangkat gawai, hingga olahraga.

Pada implementasi permainan khususnya pada olahraga bisa dikembangkan berdasarkan kebutuhan dan suasana. Pada kesempatan ini tim mencoba melakukan rancang bangun perangkat permainan guna mendukung dan melatih ketangkasan penggunanya. Perangkat berbasis mikrokontroler ini menggunakan modul Arduino Nano sebagai pengolah utamanya, dan menempatkan algoritma pengacakan secara otomatis dengan menggunakan visualisasi berupa LED. Masukan sistem berupa respon yang dihasilkan dari sensor penghalang inframerah.

Algoritma pengacakan akan melakukan visualisasi secara acak dan beragam, setelah memperoleh respon dari penggunanya. Simulator sistem permainan ini terdiri dari 7 kombinasi masukan sensor penghalang inframerah dan 7 keluaran visualnya. Sistem telah berhasil merespon secara realtime dan algoritma pengacakan dapat menghasilkan keragaman visualisasi luarannya sesuia dengan yang diharapkan.
\end{abstract}

Kata kunci : arduino, mikrokontroler, realtime, random, Arduino

\section{PENDAHULUAN}

Permainan merupakan salah satu media yang banyak digunakan masyarakat untuk sedikit meluangkan waktunya melepas penat dan jenuh disela-sela kegiatan hariannya. Berbagai upaya pelakunya, dilakukan mulai dari yang sederhana dengan permainan pada perangkat gawainya, olah raga ringan hingga olah fisik layaknya seorang atlit.

Sasaran permainan ketangkasan dengan olah fisik ini menjadi sasaran utama tema penelitian pada kesempatan ini, dengan harapan akan mampu mengembangkan bahan pengembabgnan sarana olah raga berbasis pada permainan sebagai sarana latihan layaknya sebuah permainan. Sistem dirancang dengan menggunakan unit pengolah utamanya berupa mikrokontroler.

Teknologi mini komputasi pada perangkat mikrokontroler telah banyak digunakan dan dikembangkan oleh para produsennya sebagai indikator yang mendukung headline Internet of Things, yang hingga saat ini telah dirasakan dan terimplementasi pada bagian sisi aspek kegiatan keseharian masyarakat penggunanya.

\section{PERUMUSAN MASALAH}

Model permasalahan yang tersebut dalam latar belakang menjadi bahan kajian masalah utama dalam perancangan sistem ini. Penelitian ini akan memfokuskan pada masalah perancangan perangkat permainan ketangkasan bagi sarana olah raga.

\section{BATASAN MASALAH}

Adapun batasan masalah dalam kesempatan penelitian ini adalah :

a. Desain sistem menggunakan modul mikrokontroler Arduino Nano

b. Pemrograman sistem menyisipkan teknik randomisasi nilai keluaran berdasarkan respon masukan terpilih 


\section{TUJUAN DAN MAFAAT PENELITIAN}

Adapun tujuan dalam penelitian pada kesempatan kali ini adalah :

a. Mengimplementasikan sebuah model permainan ketangkasan berbasis mikrokontroler

b. Mengetahui prinsip dasar algoritma pengacakan data

Manfaat yang ingin dicapai dalam penelitian ini adalah :

a. Memberikan wawasan pemrograman modul sistem cerdas berbasis mikrokontroler

b. Memberikan wawasan perancangan model implementatif algoritma pengacakan data

\section{METODE PENELITIAN}

Metode yang akan digunakan dalam penelitian ini terdiri dari langkah-langkah sebagai berikut ;

\section{Studi Literatur}

Untuk memperoleh dasar teori dan pustaka kajian berkaitan dengan pemanfaatan mikrokontroler sebagai komponen dari Internet of Things, baik berasal dari jurnal, buku maupun informasi baku lainnya yang bersumber dari situs-situs dan diskusi forum bebas terkait tema mikrokontroler dan teknik pengacakan data di internet

\section{Pemrograman Aplikasi}

Pemrograman aplikasi ini dimaksudkan untuk menguji sebuah teknik pengacakan data serta mengeksplorasi teknik interfacing dan mengimplementasikannya teknik/metode tersebut dalam sebuah sistem permainan ketangkasan berbasis Arduino Nano, dengan menggunakan software bantu IDE Arduino berbasis PC.

\section{HASIL DAN PEMBAHASAN}

Pada kesempatan penelitian ini, dilakukan pengamatan terhadap algoritma pengacakan data berdasarkan perubahan sensor masukan yaitu sensor penghalang inframerah, dengan ketentuan sebagai berikut :

a. Perubahan data berdasarkan pada sejumlah data digital masukan sebagai respon dari sensor penghalang inframerah (6 data digital komparatif)

b. Perubahan luaran visual berupa sejumlah data digital dengan indikasi LED (6 data kombinasi acak)

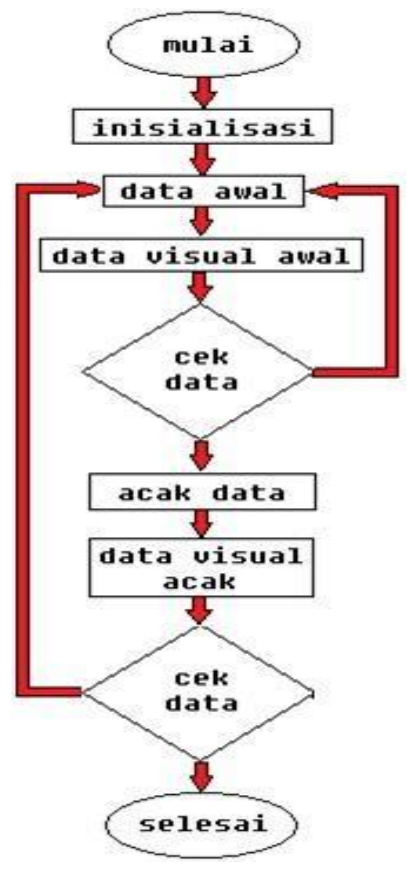

Gambar 1. Diagram alir sistem 


\section{Inisialisasi}

Inisialisasi merupakan proses alternatif untuk menguji kesiapan sistem untuk bisa beroperasi dengan baik, prosedur ini seperti mengenali status data awal pada data masukan dan penetapan data visual awal pada keluaran. Contoh yang dapat diiimplementasikan pada proses ini adalah visualisasi hasil inisialisasi dengan menggunakan indikator LED yang menyala secara bersamaan ataupun satu pin aktif sebagai hasil awal nilia acak yang telah dilakukan oleh sistem.

\section{Cek data}

Proses ini akan senantiasa memantau perubahan data yang mungkin terjadi pada masukan sensor penghalang inframerah terkait dengan kondisi status dari perubahan masukan sensor yang aktif pada posisi LED yang menyala, yang akan diperbandingkan dengan data sebelumnya. Adapun status tombol aktif dapat digambarkan dalam tabel berikut.

Tabel 1. Status masukan aktif

\begin{tabular}{|l|l|l|}
\hline $\begin{array}{c}\text { Kondisi awal } \\
\text { keluaran }\end{array}$ & $\begin{array}{c}\text { Aktifasi awal } \\
\text { masukan }\end{array}$ & \multicolumn{1}{c|}{ Keterangan } \\
\hline LED X & SENSOR Y & LED pertama - Sensor pertama \\
\hline LED X+1 & SENSOR Y+1 & LED ke dua - Sensor ke dua \\
\hline LED $X+2$ & SENSOR Y +2 & LED ke tiga - Sensor ke tiga \\
\hline LED X+3 & SENSOR Y+3 & LED ke empat - Sensor ke empat \\
\hline LED X+4 & SENSOR Y+4 & LED ke lima - Sensor ke lima \\
\hline LED X+5 & SENSOR Y+5 & LED ke enam - Sensor ke enam \\
\hline
\end{tabular}

Visualisasi data pada keluaran (LED X) merupakan hasil dari pengacakan data, dan setelah sistem pengacakan data ini, maka sensor tepilih (SENSOR Y) akan menunggu untuk dapat menerima perubahan pada masukan sensor penghalang inframerah, yang menyulut fungsi pengacakan data berikutnya, yang berlangsung secara terus menerus dan realtime.

\section{Analisa Hasil}

Pengamatan analisa program pada sistem permainan ini adalah pada upaya pengacakan data yang terus menerus dan realtime, sehingga dapat dilakukan visualisasi beragam dan berkelanjutan. Algoritma sistem pengacakan data tersebut dapat diamati dalam gambar berikut ini.

Pengacakan dilakukan dengan mengawali penentuan data yang ditandai dengan posisi LED X, kemudian proses pengacakan akan mulai setelah adanya respon masukan dari sensor penghalang inframerah, dan telah divisualisasi pada luaran sebelumnya, dimana data ini dijadikan rujukan perubahan status data keluaran, dengan terlebih dahulu melakukan komparasi antara data masukan sensor dan data visual sebelumnya. Adapun 2 prosedur yang digunakan adalah sebagai berikut.

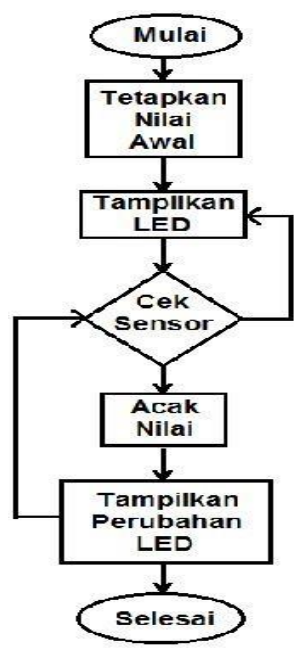

Gambar 2. Pengacakan data 
Pertama, yaitu ketersediaan dalam library fungsi pada IDE Arduino adalah fungsi random(), merupakan fungsi yang akan menghasilkan nilai pseudo-random, yang memiliki prosedur penulisan sintaksnya adalah random(max) dan random(min,max), dimana min adalah nilai minimun pengacakan dan max adalah nilai maksimum-1 pengacakan. Adapaun contoh penggunaan prosedurnya adalah sebagai berikut.

random(3);

maka proses akan melakukan pengacakan dengan keluaran nilai antara 0-2 saja

random(3,5);

maka proses akan melakukan pengacakan pada keluaran nilai antara 3-4 saja

Kedua adalah fungsi randomSeed(), merupakan library pengcakan yang akan menghasilkan varian nilai acak yang dapat diambil berdasarkan pengacakan masukan, misalnya berdasarkan pada perubahan nilai analog yang dihasilkan dari perubahan nilai sensor, yaitu menggunakan analogRead(). Untuk bentuk prosedurnya dapat dicontohkan sebagai berikut.

randomSeed(analogRead $(0))$;

maka perubahan nilai maksimum dalam pengacakan bergantung pada perubahan nilai masukan dari sensor, sehingga akan menghasilkan nilia hasil pengacakan yang lebih variatif dan beragam.

\section{KESIMPULAN}

Adapun beberapa kesimpulan yang berhasil diperoleh dalam penelitian ini diantaranya adalah sebagai berikut :

a. Proses pengacakan data dapat dilakukan dengan komparasi perubahan pada data sebelumnya dan menghasilkan data visual keluaran yang beragam dan terus menerus secara realtime.

b. Metode fungsi random() dapat lebih diberikan variasi nilai pengacakan dengan metode randomSeed().

\section{DAFTAR PUSTAKA}

[1] E. Nurraharjo, 2011, "Analisis Model Akuisisi Data Terhadap Piranti Analog To Digital (ADC)", Dinamik-Jurnal Teknologi Informasi

[2] E. Nurraharjo, 2012, "Terminal Port Komputer sebagai Perantara Pemrograman Bahasa Tingkat Tinggi”, Dinamik-Jurnal Teknologi Informasi.

[3] E. Nurraharjo, 2012, "Implementasi Image Statistic Method pada Pengolahan Citra Digital", Dinamik- Jurnal Teknologi Informasi

[4] E. Nurraharjo, 2013, " Rangkaian Pembangkit Gelombang dengan menggunakan IC XR-2206", Dinamik-Jurnal Teknologi Informasi.

[5] Z. Budiarso, EN. Raharjo, V. Lusiana, 2006, Laporan Penelitian, "Sistem Kendali Terpadu dengan Menggunakan Metode Octal Bus Transceiver with Non Inverting 3 State Output" 